\title{
DIFFERENT BRAIN STRUCTURES EXHIBIT THE SAME CAFFEINE LEVELS AFTER THE ADMINISTRATION OF A SINGLE DOSE OF CAFFEINE
}

\author{
Mary Orrego Cardozo ${ }^{1}$ \\ Alejandro Jiménez-Rodriguez² \\ Alejandro Osorio-Forero ${ }^{3}$ \\ Francia Restrepo 4 \\ Juan Miguel Arias ${ }^{5}$ \\ Lukas Tamayo-Orrego ${ }^{6}$
}

\begin{abstract}
Caffeine is a highly consumed stimulant of the nervous system. Although caffeine has diverse effects on different brain functions, little is known about the specific pharmacokinetics of this substance in the brain. For instance, most studies that assessed caffeine distribution in the rat brain have only measured caffeine levels in the cortex and striatum but not in more specific brain areas.Aims: The purpose of this work was to measure the caffeine concentration in blood and different brain regions (i.e. cortex, striatum, hippocampus, cerebellum and brainstem) at different times after the administration of a single intraperitoneal dose of caffeine.Methods: Adult Wistar rats (250 to 300 gr) were injected with a single intraperitoneal dose of $30 \mathrm{mg} /$ $\mathrm{Kg}$ of caffeine. 20,40, 60 and 80 minutes after administration, subjects were sacrificed by decapitation and samples of plasma, cerebral cortex, striatum, hippocampus, cerebellum and brainstem were obtained. Caffeine levels in the blood and each brain structure were
\end{abstract}

measured by RP-HPLC and statistical analysis was performed. Results: Caffeine levels were higher in the plasma compared to all the brain structures studied. Different brain regions displayed similar caffeine concentrations. For all brain regions, the maximal concentration levels of caffeine were reached in the first 40 minutes after caffeine administration.Conclusions: The results support previous studies that show similar caffeine concentration between cortex and striatum, but also extend the results to other brain structures. Furthermore, caffeine concentration increases similarly in the plasma and brain structures. 40,60 and 80 minutes after administration, caffeine concentration in the blood is almost two times higher than in the brain. This suggests that the effects of caffeine on different brain functions do not depend on pharmacokinetic differences between brain areas and are rather explained by pharmacodynamics.

Key words: ebrain, caffeine, HPLC, pharmacokinetics, plasma.

\footnotetext{
${ }^{1}$ PhD Bioquímica y Biología Molecular. Laboratorio de Neurofisiología. Universidad Autónoma de Manizales. Manizales, Caldas. Colombia. Correo electrónico: maryorrego@autonoma.edu.co. Departamento de Física y Química, Universidad Nacional de Colombia-Sede Manizales. Correo electrónico: morregoc@unal.edu.co.

2 M.Sc. Matemáticas Aplicadas. Laboratorio de Neurofisiología. Universidad Autónoma de Manizales. Manizales, Caldas. Colombia. Correo electrónico: alejandro.jimenez@blbt.uni-freiburg.de

3 Ingeniería Biomédica. Laboratorio de Neurofisiología. Universidad Autónoma de Manizales. Manizales, Caldas. Colombia. Correo electrónico: alejosorio1@gmail.com

${ }^{4}$ PhD. Ciencias sociales, niñez y juventud. Laboratorio de Neurofisiología. Universidad Autónoma de Manizales. Manizales, Caldas. Colombia. Correo electrónico: franciarestrepo@autonoma.edu.co

${ }^{5}$ MSc, Psicología Evolucionaria y Comparativa. Laboratorio de Neurofisiología. Universidad Autónoma de Manizales. Manizales, Caldas. Colombia. Correo electrónico: juanm.arias42@gmail.com.

${ }^{6}$ Médico Cirujano. Laboratorio de Neurofisiología. Universidad Autónoma de Manizales. Manizales, Caldas. Colombia. Correo electrónico: lukastamayo@gmail.com
} 


\section{ESTRUCTURAS ENCEFÁLICAS DISTINTAS MUESTRAN CONCENTRACIÓN DE CAFEÍNA SIMILAR DESPUÉS DE LA ADMINISTRACIÓN DE UNA DOSIS ÚNICA}

\section{RESUMEN}

Antecedentes: La cafeína es el estimulante del sistema nervioso más consumido a nivel mundial. Aunque, la cafeína tiene diferentes efectos sobre las funciones cerebrales, poco se sabe acerca de su farmacocinética en el cerebro. Por ejemplo, la mayoría de estudios que evaluaron la distribución de cafeína en el cerebro de rata han medido niveles de cafeína en corteza y estriado, pero no en áreas cerebrales más específicas. Objetivo: El propósito del trabajo fue medir la concentración de cafeína en sangre y diferentes regiones encefálicas (corteza, estriado, hipocampo, cerebelo, tallo cerebral), a diferentes tiempos, después de administrar una única dosis de cafeína. Método: Ratas Wistar adultas (250-300 gr) recibieron una dosis intraperitoneal de cafeína de 30mg/Kg de peso. 20, 4060 y 80 minutos después de la administración, los sujetos se sacrificaron por decapitación y se

\section{INTRODUCTION}

Caffeine has important effects on different brain functions such as motor behavior, attention, memory and learning (1-6). Caffeine acts on dopamine, GABA, NMDA and Ryanodine receptors (7-10), and as a competitive antagonist of adenosine receptors $(2,10)$. The differential effects of caffeine on behavior and cognition are thought to depend on its specificity for different receptor types (10). Since different brain regions have different number, composition and combinations of neurotransmitter receptors, the effects of caffeine on the central nervous system (CNS) are thought to be explained mainly by pharmacodynamic mechanisms $(8,10)$. obtuvieron muestras de plasma, corteza cerebral, estriado, hipocampo, cerebelo y tallo cerebral. Los niveles de cafeína en plasma y estructuras encefálicas se determinaron por RP-HPLC y se realizó análisis estadístico.

Resultados: Los niveles de cafeína fueron mayores en plasma que en las regiones encefálicas estudiadas. Las distintas regiones encefálicas presentaron concentraciones similares de cafeína. En todas las regiones, la mayor concentración de cafeína se obtuvo 40 minutos después de la administración de cafeína.

Conclusiones: Este estudio soporta resultados previos que muestran concentraciones similares de cafeína entre la corteza y el estriado, además los extiende a otras regiones encefálicas. La concentración de cafeína aumenta similarmente en plasma y estructuras encefálicas. 40, 60 y 80 minutos después de la administración, la concentración de cafeína en plasma es casi el doble de la encontrada en el cerebro. Lo anterior sugiere que los efectos de la cafeína en distintas funciones cerebrales no dependen de diferencias farmacocinéticas entre regiones encefálicas sino que son más bien explicadas por factores farmacodinámicos.

Palabras clave: encéfalo, cafeína, HPLC, farmacodinámica, plasma.

However, the effects of caffeine can still depend on pharmacokinetic mechanisms, as differential effects of caffeine have been described according to the administered dose; for example, low doses $(2.5 \mathrm{mg} / \mathrm{Kg})$ in rats activate dopaminergic circuits involved in locomotor behavior, while higher doses $(10 \mathrm{mg} / \mathrm{Kg}$ ) affect pathways and structures responsible for reward and pleasure (11). Similarly, acute administration of caffeine impairs learning (12), whereas chronic intake during adulthood may prevent memory decline (13). Thus, while these distinct effects of caffeine on different brain functions and regions could be explained by the differential distribution of neurotransmitter receptors involved in specific brain circuits $(14,15)$, differences in caffeine 
distribution across brain areas (16) could also account for the varied effects of caffeine on cognitive processes and behavior (1).

The early kinetics of caffeine between different brain structures is not well known; whereas most studies compare caffeine levels in the brain compared to plasma, few studies have explored the distribution of caffeine across structures of the CNS. In those cases, the comparison is made between cortical and subcortical regions; for instance, Carey and De Palma (16) found higher caffeine concentrations in the cerebral cortex compared to the striatum, while Ferré et al. (17) found opposite results. Moreover, the patterns of caffeine distribution in the hippocampus and cerebellum, regions important for memory and motor behavior, respectively, have not been studied.

In this study, we determined the relationships between caffeine concentration in the plasma and different brain structures, including the cerebral cortex, hippocampus, striatum, cerebellum and brainstem 20, 40, 60 and 80 minutes after the administration of a single dose of caffeine. Caffeine concentration was higher in plasma than in all the brain structures studied at 40,60 at 80 minutes. We did not find significant differences in caffeine levels between the brain structures studied. These results suggest that the pharmacological effects of caffeine on different brain and cognitive functions are not influenced by pharmacokinetic differences between brain areas.

\section{MATERIALS AND METHODS}

Animals: 25 Adult Wistar rats (250 to 300 gr) were kept in the animal facility under standard conditions. We followed the National Institutes of Health (NIH) guidelines for the use of laboratory animals (18) and the EU Directive 2010/63/EU for animal experiments (19); the animal protocol was approved by the ethics committee of the Universidad Autónoma de Manizales (act no. 015-2011).
Caffeine administration and collection of tissue samples: 5 rats were used as a control group. This group was injected with $0.3 \mathrm{ml}$ of distilled water and sacrificed at time $0 \mathrm{~min}$. For the rest of the animals, the required amount of caffeine (Merck ${ }^{\circledR}$, Darmstadt) for a concentration of $30 \mathrm{mg} / \mathrm{Kg}$ was calculated according to its weight. This amount was diluted in $0.3 \mathrm{ml}$ of water (Honeywell Burdick \& Jackson $®$ ) and administered by a single intraperitoneal dose to each rat. These animals were sacrificed in groups of 5 by decapitation at time 20, 40, 60 and 80 minutes after caffeine administration. A plasma sample was obtained and cerebral cortex, hippocampus, striatum, cerebellum and brainstem tissues were dissected from the brain, weighted, and frozen at $-20 \mathrm{C}$.

Pre-treatment of frozen samples: The Serra et al. (20) method was modified as follows: $50 \mu \mathrm{l}$ of $1 \%$ ascorbic acid (Carlo Erba®, Milan) and $100 \mu$ l of $4 \%$ phosphoric acid (Carlo Erba ${ }^{\circledR}$, Milan) were added to each $60 \mathrm{mg}$ of tissue. $400 \mu \mathrm{l}$ of a water / methanol (Honeywell Burdick \& Jackson) /4\% phosphoric acid solution (at a v/v/v proportion of $94 / 4.5 / 1.5$, solution A) were added to each sample. After tissues were homogenized for 2 minutes, $1200 \mu \mathrm{l}$ of solution A were added to the each sample and homogenized during 4 additional minutes. Samples were centrifuged at $17.150 \mathrm{~g}$ for 15 minutes at $4 \mathrm{C}$ and the supernatants were collected and stored at $-20 \mathrm{C}$.

Caffeine extraction: Caffeine was extracted using a solid-phase extraction column (SPE Cartridge C18, $1 \mathrm{ml}$, RESPREP-Restek ${ }^{\circledR}$, Philadelphia). The column was conditioned with $1 \mathrm{ml}$ methanol and $1 \mathrm{ml} \mathrm{H}_{2} \mathrm{O}$, and the samples were loaded and allowed to drain by gravity; the columns were subsequently loaded with 1 $\mathrm{ml} \mathrm{H}_{2} \mathrm{O}$, and caffeine was finally eluted in $1 \mathrm{ml}$ methanol. The eluted samples were filtered using discs of regenerated cellulose $(0.2 \mu \mathrm{m}$, 52225-RC, Titian) and kept in vials for reversed phase high performance liquid chromatography (RP-HPLC) quantification. 
Blood samples were centrifuged for 10 minutes to isolate the plasma. Plasma samples were loaded into the SPE columns and processed as the brain samples.

Determination of caffeine concentration by RPHPLC: A LC-2010AHT Shimadzu-LC®liquid chromatography apparatus with an UV detector LC-2010 and aC18 Premier column (150 mm x $4.0 \mathrm{~mm}$ ) were used. The mobile phase consisted of methanol (solvent A) and water (solvent B). From the time of sample injection, a gradient of $30 \%$ of $A$ and $70 \%$ of B was set up and held for 6 minutes, after which it finished with $100 \%$ of $A$. The flow rate was $1 \mathrm{~mL} /$ minute. The wavelength of the detector was set at $278 \mathrm{~nm}$.
Validation method: The caffeine standard was prepared by diluting $2 \mathrm{mg}$ of caffeine in $1 \mathrm{ml}$ of methanol. The peaks in the chromatogram were identified by comparison with the retention of the caffeine standard. The eluting peak of the caffeine was present between $3.7 \mathrm{~min}$ and $4.2 \mathrm{~min}$ (figure 1b). The calibration curve was constructed using dilutions of the caffeine standard in a $0.01-2.0 \mathrm{mg} / \mathrm{ml}$-concentration range (figure 1a). $20 \mu \mathrm{l}$ aliquots of each dilution were injected directly into the RP-HPLC. All injections were also performed in triplicate. The linear regression analysis for testing linearity was performed by plotting the area under the peaks against caffeine concentrations.

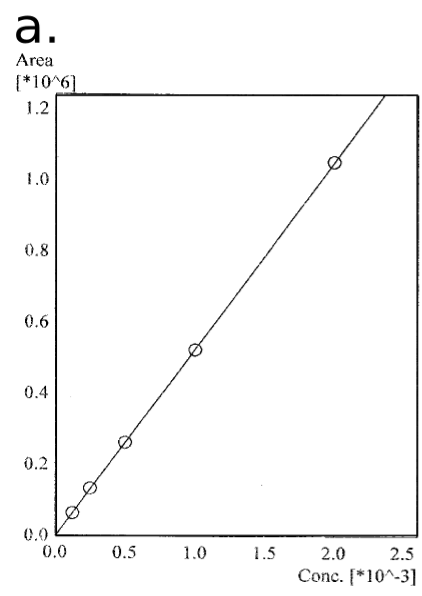

b.

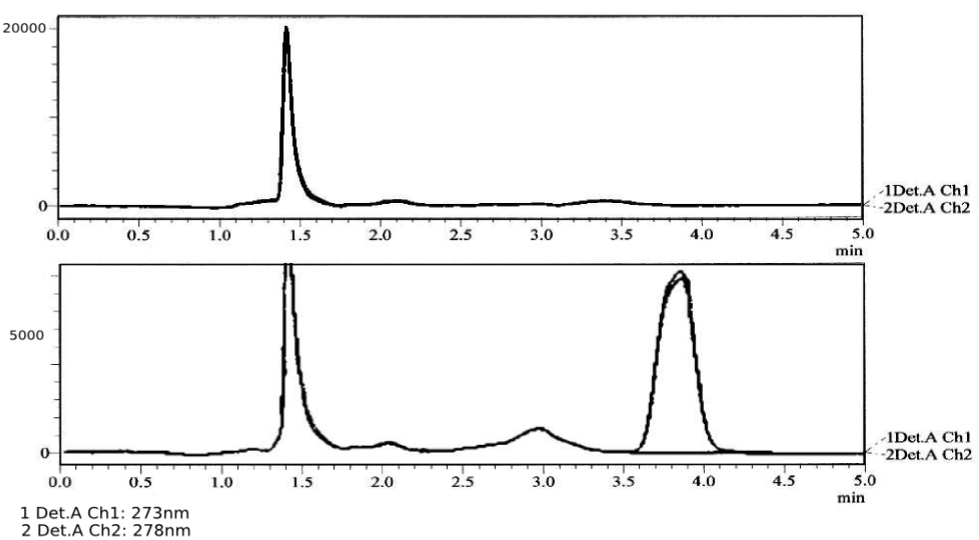

Figure 1.a. Caffeine calibration curve. $X$-axis: caffeine concentration, y-axis: area under the peaks. b. Examples of chromatograms showing two samples, one from the control group (Brainstem, $0 \mathrm{~min}$. Top) and another from a caffeine treated animal (Cortex, $40 \mathrm{~min}$. Bottom). The mobile phase consisted of methanol (solvent A) and water (solvent B). From the time of sample injection, a gradient of $30 \%$ of $A$ and $70 \%$ of $B$ was set up and held for 6 minutes, after which it finished with $100 \%$ of $\mathrm{A}$. The flow rate was $1 \mathrm{~mL} /$ minute and the wavelength of the detector was set at $278 \mathrm{~nm}$. The caffeine peak eluted between $3.7 \mathrm{~min}$ and $4.2 \mathrm{~min}$. and the peaks for theobromine and theophylline around 2 and 3 minutes respectively.

Statistical analysis: We used the software SPSS V.20 (IBM) to perform the statistical comparisons between groups. In this work, at each time, nonparametric comparisons were made between brain tissues using the Kruskall-Wallis test, and between each brain tissue with plasma using the Mann-Withney test. 


\section{RESULTS}

Caffeine concentration is higher in the plasma compared to brain structures: After a single dose of $30 \mathrm{mg} / \mathrm{Kg}$, we observed higher concentrations of caffeine in the plasma compared to the brain $(p<0.01)$, at 40,60 and 80 minutes. At these times, caffeine concentration in brain structures was about $50 \%$ of caffeine level in plasma. Furthermore, caffeine concentration in plasma did not show significant decline in the time range of the study (Figure 2).

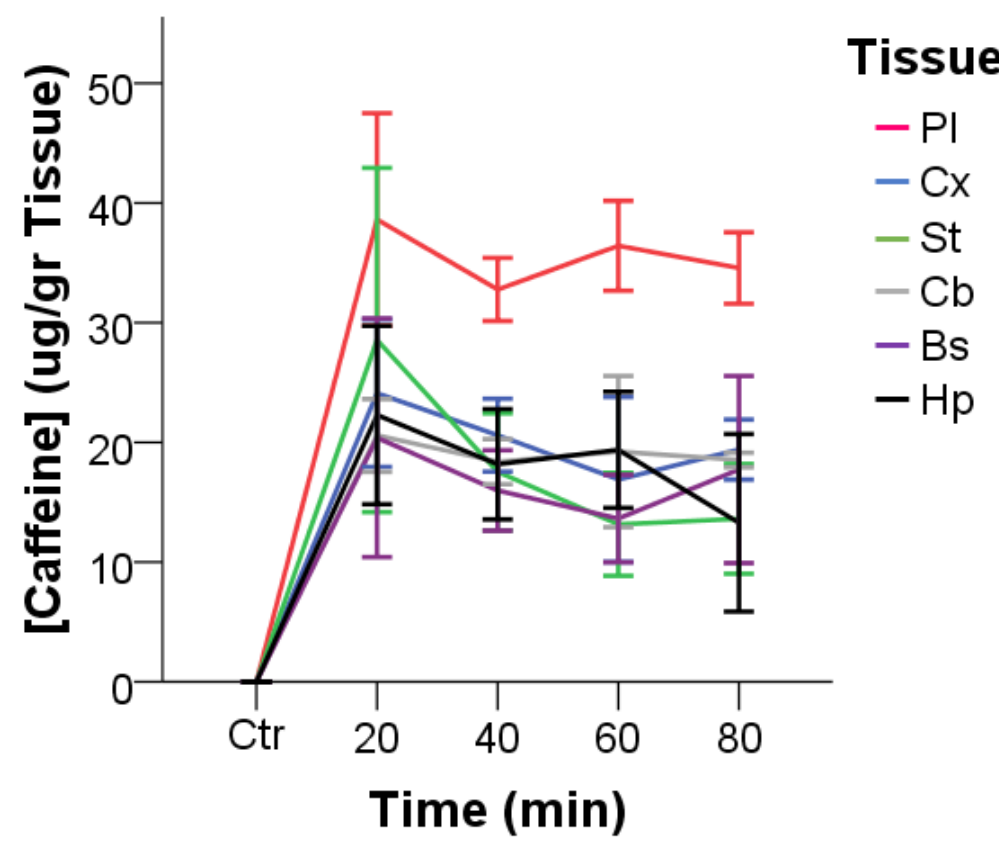

Figure 2 Caffeine Concentration-time profile in the plasma $(\mathrm{Pl})$, cerebral cortex $(\mathrm{Cx})$, striatum $(\mathrm{St})$, cerebellum $(\mathrm{Cb})$, hippocampus $(\mathrm{Hp})$, brainstem $(\mathrm{Bs})$, and the brain average (Avg). Asteriks above the traces indicate significant difference compared to plasma, $\mathrm{p}<0.01$. Controls were plotted at $0 \mathrm{~min}$.

Caffeine concentration is similar across brain structures: We did not find significant differences in caffeine concentration between the brain structures studied (Kruskal-Wallis $\mathrm{p}>0.05$ ).
In brain structures, the maximal concentration of caffeine was reached in the first 40 minutes after caffeine administration (Table 1). 
Table 1. Mean Caffeine concentration ( $\mu \mathrm{g} / \mathrm{gr}$ tissue) and standard deviation (SD) in plasma and five brain structures. Pl: Plasma. Cx: Cerebral cortex. St: Striatum. Hp: hippocampus. Cb: Cerebellum. Bs: Brainstem. Brain: Mean caffeine concentration in all the regions studied (*) significant difference compared to plasma, $\mathrm{p}<0.01$. For all samples in the control group no significant concentrations were detected.

\begin{tabular}{ccccc}
\hline \multirow{2}{*}{ Tissue } & \multicolumn{4}{c}{ Time (min) } \\
\cline { 2 - 5 } & $\mathbf{2 0}$ & $\mathbf{4 0}$ & $\mathbf{6 0}$ & $\mathbf{8 0}$ \\
\hline $\boldsymbol{P l}$ & $31.84(16.05)$ & $31.98(2.64)$ & $35.64(3.76)$ & $33.77(3.45)$ \\
$\boldsymbol{C} \boldsymbol{x}$ & $24.11(6.16)$ & $20.6(3.04)^{*}$ & $16.91(6.89)^{*}$ & $19.4(2.9)^{*}$ \\
$\boldsymbol{S} \boldsymbol{t}$ & $28.55(14.38)$ & $17.54(4.89)^{*}$ & $13.16(4.3)^{*}$ & $13.61(4.58)^{*}$ \\
$\boldsymbol{C b}$ & $19.98(3.04)$ & $17.79(1.89)^{*}$ & $18.63(6.32)^{*}$ & $17.93(0.61)^{*}$ \\
B $\boldsymbol{H}$ & $19.57(9.97)$ & $15.16(3.36)^{*}$ & $12.82(3.65)^{*}$ & $16.91(7.82)^{*}$ \\
$\mathbf{H} \boldsymbol{B r a i n}$ & $21.48(7.45)$ & $17.37(4.61)^{*}$ & $18.57(4.85)^{*}$ & $12.47(7.42)^{*}$ \\
Brain & $23.18(8.81)$ & $18.14(3.72)^{*}$ & $16.46(5.58)^{*}$ & $16.39(5.63)^{*}$ \\
\hline
\end{tabular}

\section{DISCUSSION}

We studied the concentration of caffeine in different structures of the brain and plasma at different times after an intraperitoneal injection of $30 \mathrm{mg} / \mathrm{Kg}$ of caffeine in rats. Our results are not expected to differ from those obtained by other methods of administration, such as oral or subcutaneous, because they show similar pharmacokinetic curves in plasma (8). Furthermore, the selected dose is in accordance with previous studies $(16,17,21,23)$.

Additional small peaks related to the caffeine metabolites theophylline and theobromine (24) were present in the chromatograms. However, as can be seen in Figure 1, those peaks do not interfere with the identification of the caffeine peak, which was well separated in all samples. We focused our analysis on the caffeine peak.

Our results indicate that the concentration of caffeine in the plasma is higher compared to the brain structures studied during the first 80 minutes after caffeine administration; these results are consistent with those found by Carey and De Palma (16), Ståhle, Segersvärd (21) and opposite to those found by Ferré et al., (17), who found higher caffeine levels in striatum and brain compared to plasma. Kaplan et al., (22) did not find differences in caffeine concentration between brain and plasma over a $4 \mathrm{~h}$ time period.

We did not observe differences in the caffeine concentration between the striatum and the cortex after a single dose of $30 \mathrm{mg} / \mathrm{Kg}$. This finding is in disagreement with the results reported by Carey and De Palma (16) who found higher caffeine levels in cortex compared to striatum with doses of 10 and $50 \mathrm{mg} / \mathrm{Kg}$, 40 minutes after administration. The results were also in disagreement with Ferré et al. (17), who found higher levels of caffeine in the striatum than in the cortex between 5 and 25 $h$ after caffeine administration. Nevertheless, our results and those reported by Stahle et al. (21) and Kaplan et al. (22) indicate that there are no differences in the levels of caffeine between different brain structures during the first 80 minutes after a single dose of caffeine is administered.

An important observation is the high intersubject variability at different times. Indeed, 
after 20 minutes after caffeine administration, all the regions and the blood display a high variance, which explains the lack of significance found in our analysis. This variability is lower at all subsequent time-points. This result indicates that the time to reach the peak concentration of caffeine is highly dependent on individual differences and more stable for the clearance phase.

However, the fact that we observed clear differences in the caffeine concentration between plasma and brain indicates that this HPLC-based method for caffeine quantification was sensitive enough and that the absence of differences between brain structures at the time-points studied is real. The present results suggest that the effects of caffeine on different behaviors cannot be explained by the differential distribution of caffeine (pharmacokinetics) in different brain regions and could be rather explained mainly by pharmacodynamic mechanisms, as suggested by Fredholm et al. (8) and Yoshimura (10).

\section{CONCLUSIONS}

The present results indicate that the concentration of caffeine is higher in plasma compared to brain structures at 40,60 and 80 minutes after caffeine administration; yet, caffeine appears to be homogeneously distributed across different brain regions during the first 80 minutes. These results suggest a non-linear relationship between the concentration of caffeine in the plasma and brain structures and also supports the hypothesis that pharmacokinetic mechanisms are insufficient to account for the diverse effects of caffeine in the brain.

\section{ACKNOWLEDGEMENTS}

We would like to thank Rocío del Pilar Pineda Sandoval for help with sample processing for RP-HPLC. This work was supported by Universidad Autónoma de Manizales. Project code: 250-028. The authors declare that there are no conflicts of interest.

\section{REFERENCES}

1. Nehlig A. Is caffeine a cognitive enhancer? J AlzheimersDis. 2010; 20:85-94.

2. Ribeiro JA, Sebastião AM. Caffeine and adenosine. J Alzheimers Dis.. 2010; 20:3-15.

3. Cunha RA, Agostinho PM. Chronic caffeine consumption prevents memory disturbance in different animal models of memory decline. J Alzheimers Dis. 2010; 20: 95-116.

4. Santos C, Lunet N, Azevedo A, de Mendonça A, Ritchie K, Barros H. Caffeine intake is associated with a lower risk of cognitive decline: a cohort study from Portugal. J Alzheimers Dis. 2010; 20:175-85.

5. Borota, D, Murray, E., Keceli, G., Chang, A., Watabe, J.M., Ly, M., Toscano, J.P. and Yassa, M.A. "Poststudy caffeine administration enhances memory consolidation in humans." Nature neurosc 2014; 17(2):201-203.

6. Chen J-F, Yu L, Shen H-Y, He J-C, Wang X, Zheng R. What knock-out animals tell us about the effects of caffeine. J AlzheimersDis. 2010; 20:17-24.

7. McPherson PS, Kim Y-K, Valdivia H, Knudson CM, Takekura H, Franzini-Armstrong $\mathrm{C}$, et al. The brain ryanodine receptor: a caffeine-sensitive calcium release channel. Neuron. 1991; 7(1):17-25.

8. Fredholm BB, Bättig K, Holmén J, Nehlig A, Zvartau EE. Actions of caffeine in the brain with special reference to factors that contribute to its widespread use. Pharmacol. Rev. 1999; 51(1):83-133.

9. Solinas M, Ferré S, You Z-B, Karcz-Kubicha M, Popoli P, Goldberg SR. Caffeine induces dopamine and glutamate release in the shell of the nucleus accumbens. J. Neurosci. 2002; 22(15):6321-4. 
10. Yoshimura $\mathrm{H}$. The potential of caffeine for functional modification from cortical synapses to neuron networks in the brain. CurrNeuropharmacol. 2005; 3(4):309.

11. Nehlig A, Boyet S. Dose-response study of caffeine effects on cerebral functional activity with a specific focus on dependence. Brain Res. 2000; 858(1):71-7.

12. Corodimas KP, Pruitt JC, Stieg JM. Acute exposure to caffeine selectively disrupts context conditioning in rats. Psychopharmacology. 2000; 152(4):376-82.

13. Costa M, Botton P, Mioranzza S, Souza D, Porciuncula L. Caffeine prevents age-associated recognition memory decline and changes brain-derived neurotrophic factor and tirosine kinase receptor (TrkB) content in mice. Neurosc. 2008;153(4):1071-8.

14. Acquas E, Tanda G, Di Chiara G. Differential effects of caffeine on dopamine and acetylcholine transmission in brain areas of drug-naive and caffeine-pretreated rats. Neuropsychopharmacology. 2002;27(2):182-93.

15. Ballesteros-Yáñez I, Castillo CA, Amo-Salas M, Albasanz JL, Martín M. Differential Effect of Caffeine Consumption on Diverse Brain Areas of Pregnant Rats. J Caffeine Res. 2012; 2(2):90-8.

16. Carey RJ, De Palma G. A simplified method for the measurement of caffeine in plasma and brain: evidence for a cortical-subcortical caffeine concentration differential in brain. J. Neurosci. Methods. 1994; 53(1):19-22.

17. Ferré $S$, Guix T, Sallés J, Badia A, Parra $P$, Jané $F$, et al. Paraxanthine displaces the binding of $[<$ sup $>$ 3</sup> H] SCH 23390 from rat striatal membranes. Eur. J. Pharmacol. 1990; 179(3):295-9.

18. Guide for the Care and Use of Laboratory Animals: Eighth Edition: The National Academies Press; 2011.

19. Parliament E, Union tCotE. Directive 2010/63/EU of the European Parliament and of the Council of 22 September 2010 on the protection of animals used for scientific purposes. Official J Eur Union. $2010 ; 276$.

20. Serra A, Macià A, Romero M-P, Pinol C, Motilva M-J. Rapid methods to determine procyanidins, anthocyanins, theobromine and caffeine in rat tissues by liquid chromatography-tandem mass spectrometry. J. Chromatogr. B. 2011; 879(19):1519-28.

21. Ståhle L, Segersvärd S, Ungerstedt U. Drug distribution studies with microdialysis II. Caffeine and theophylline in blood, brain and other tissues in rats. Life sciences. 1991; 49(24):1843-52.

22. Kirch, D.G, Taylor, G.A, Gerhart, N.L., Stephen, C. And Wyatt. Effect of chronic caffeine administration on monoamine and monoamine metabolite concentration in rat brain. Neuropharmacology. 1990; 29(6): 599-602.

23. Parra $P$, Limon A, Ferre $S$, Guix T, Jane F. High-performance liquid chromatographic separation of caffeine, theophylline, theobromine and paraxanthine in rat brain and serum. Journal of Chromatography $B$ : Biomedical Sciences and Applications. 1991 Sep 18; 570(1): 185-90.

24. Kaplan GB, Tai NT, Greenblatt DJ, Shader RI. Caffeine induced behavioural stimulation is dose and concentration dependent. $\mathrm{Br}$ J Pharmacol. 1990; 100(3):435-40. 